\title{
Black-Backed Woodpecker Nest Density in the Sierra Nevada, California
}

\author{
Chad T. Hanson ${ }^{1, *}$ and Tonja Y. Chi ${ }^{2}$ (D) \\ 1 Earth Island Institute, 2150 Allston Way, Suite \#460, Berkeley, CA 94704, USA \\ 2 Wildlife Ecologist and Private Consultant, P.O. Box 10022, South Lake Tahoe, CA 91158-3022, USA; \\ tonja_chi@hotmail.com \\ * Correspondence: cthanson1@gmail.com
}

Received: 14 August 2020; Accepted: 14 September 2020; Published: 23 September 2020

\begin{abstract}
In the western U.S., the black-backed woodpecker has been found to be associated with dense montane conifer forests with high snag densities, typically resulting from moderate- to high-severity wildland fires. However, black-backed woodpeckers are occasionally also detected nesting in unburned forests, raising questions about the type of habitat in which they nest and the potential abundance of such habitat. We conducted intensive black-backed woodpecker nest density surveys in large plots within the middle/upper-montane conifer forests of the Sierra Nevada, California, within general (undisturbed) forests, snag forest habitat from moderate/high-severity wildland fire, and unburned snag forest habitat from drought and native bark beetles. We found black-backed woodpeckers nesting only in the two snag forest conditions, mostly in burned snag forest, and their preferential selection of burned snag forest was statistically significant. No nest was found in general forests. Our spatial analysis indicates that snag forest is rare in the forests of the Sierra Nevada due to fire suppression and logging, raising concerns regarding small population size, which we estimate to be only 461 to 772 pairs in the Sierra Nevada.
\end{abstract}

Keywords: black-backed woodpecker; high-severity fire; forests; logging; rare species

\section{Introduction}

In the Sierra Nevada mountains of California, USA, the black-backed woodpecker (Picoides arcticus) is an uncommon species associated with dense middle/upper-montane conifer forests recently burned in mixed-severity wildland fires [1,2]. A high snag basal area has been found to be an important metric to predict black-backed woodpecker occupancy in burned forests [2-4]. However, black-backed woodpeckers have also been detected in unburned forests with elevated levels of snags, including in the Sierra Nevada [5], eastern Oregon [6], and the Black Hills of South Dakota [7]. This species is also known to nest and breed in late-successional and old unburned boreal forests in eastern Canada, especially in forest stands with large volumes of deadwood [8,9]. Similar research in unburned forests of the Sierra Nevada is generally lacking, however. Thus, there is uncertainty about the type and spatial extent of the existing habitat for this species, and corresponding uncertainty about the current population level of black-backed woodpeckers in the Sierra Nevada. This uncertainty is compounded by ongoing forest management practices that encourage the logging of snags in unburned forests and target dense, older forests for logging activities and the removal of mature, live trees [10].

Credible estimates of black-backed woodpecker populations have been made for some individual fire areas by Tingley et al. (2016) [11] in the Sierra Nevada mountains of California, based on visual or auditory detections at grid locations spaced by $500 \mathrm{~m}$ (with each location effectively representing an area of 25 ha). However, the authors noted that black-backed woodpeckers can have home ranges of 500 ha, raising the possibility that populations could have been overestimated due to unintended 
double-counting, and that the true management value of this methodology is the ability to estimate habitat value by relative population abundance in burned forests for the purpose of prioritizing high-quality patches for retention. Though highly labor-intensive for a given unit of area, nest density surveys provide another means to estimate populations [12].

Mixed-severity fires are a natural part of historical fire regimes in the montane conifer forests of the Sierra Nevada $[13,14]$, and the moderate/high-severity component of such fires creates the "snag forest habitat" with which black-backed woodpeckers are typically associated [14,15]. Similarly, in the unburned boreal forests of eastern Canada, black-backed woodpeckers are also associated with dense, old forests with very high levels of deadwood $[8,9,16,17]$. Snag forest habitat is now considered to be less common than it was historically in the Sierra Nevada and western U.S. forests, generally due to fire suppression and the logging of snags in both burned and unburned forests [14,18-20]. In the Sierra Nevada, black-backed woodpeckers select interior areas of large high-severity fire patches [21]. Though the occurrence of large high-severity fire patches increased from the 1980s through to the 1990s in forests of the western U.S., it has not continued to increase over the past two decades [22].

The consequences of these patterns for black-backed woodpecker populations depends in significant part on the extent to which this species nests in general (undisturbed) forests, which are far more spatially extensive than the snag forest habitat created by fire or cycles of drought and native bark beetles. The extent to which black-backed woodpeckers nest in unburned snag forest habitat (versus the snag forest habitat from wildland fire) in the Sierra Nevada, as they do in the old boreal forests of eastern Canada $[8,9,17]$, is also relevant, given the extensive pulse of snag recruitment in unburned forests that occurred mainly in 2015 and 2016 in the southern and central Sierra Nevada during extreme drought conditions, killing $>20-30 \%$ of the trees in numerous areas $[23,24]$.

We investigated this issue by conducting black-backed woodpecker nest density surveys in the general forests, unburned snag forests, and burned snag forests of the Sierra Nevada, measuring the snag basal area at nest sites and estimating the current spatial extent of snag forest habitat in these forests.

\section{Materials and Methods}

\subsection{Field Data}

Our study area comprised the middle and upper-elevation conifer forests of the Sierra Nevada management region, encompassing the forest types inhabited by black-backed woodpeckers to the southern limit of their range, just north of Lake Isabella [5]. This included mixed-conifer forests in the middle elevation areas, upper montane forests dominated by true fir, Jeffrey pine (Pinus jeffreyi), eastside pine, and lodgepole pine (Pinus contorta), and subalpine forest types in the higher elevations (Figure 1). Within this broader study area, we searched for black-backed woodpecker nests within a series of 300 ha field plots, as discussed below.

For general forests, we restricted the sampling landscape to areas $>2 \mathrm{~km}$ from any fire area 1998-present, and also excluded any areas that experienced high-severity fire [25] from 1984 to present (satellite imagery to detect and record high-severity fire occurrence became available in 1984), since such areas would not yet have regenerated into mature conifer forests following high-severity fire. Within the resulting general forest areas, 300 ha plots were systematically arranged, with the southwest corner of each plot located at the intersection of each increment of $5 \mathrm{~min}$ of longitude and latitude. Each plot was comprised of three square 100 ha subplots, with the middle subplot offset $1 \mathrm{~km}$ to the north relative to the others, and each subplot consisted of five contiguous strips $200 \mathrm{~m}$ wide and $1000 \mathrm{~m}$ long, oriented lengthwise south to north (Figure 2). 


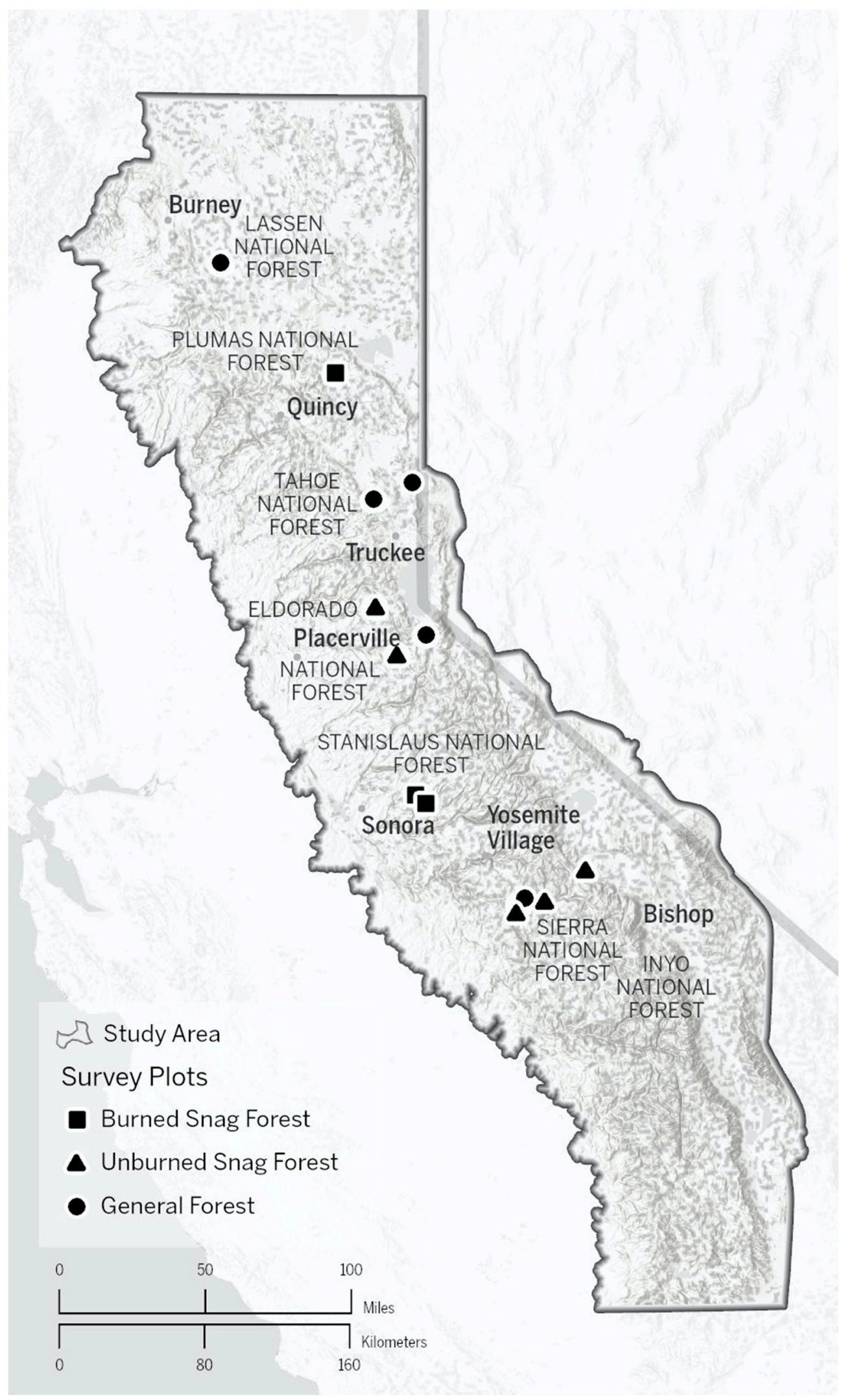

Figure 1. The study area, with the locations of plots in each of the three habitat conditions. 


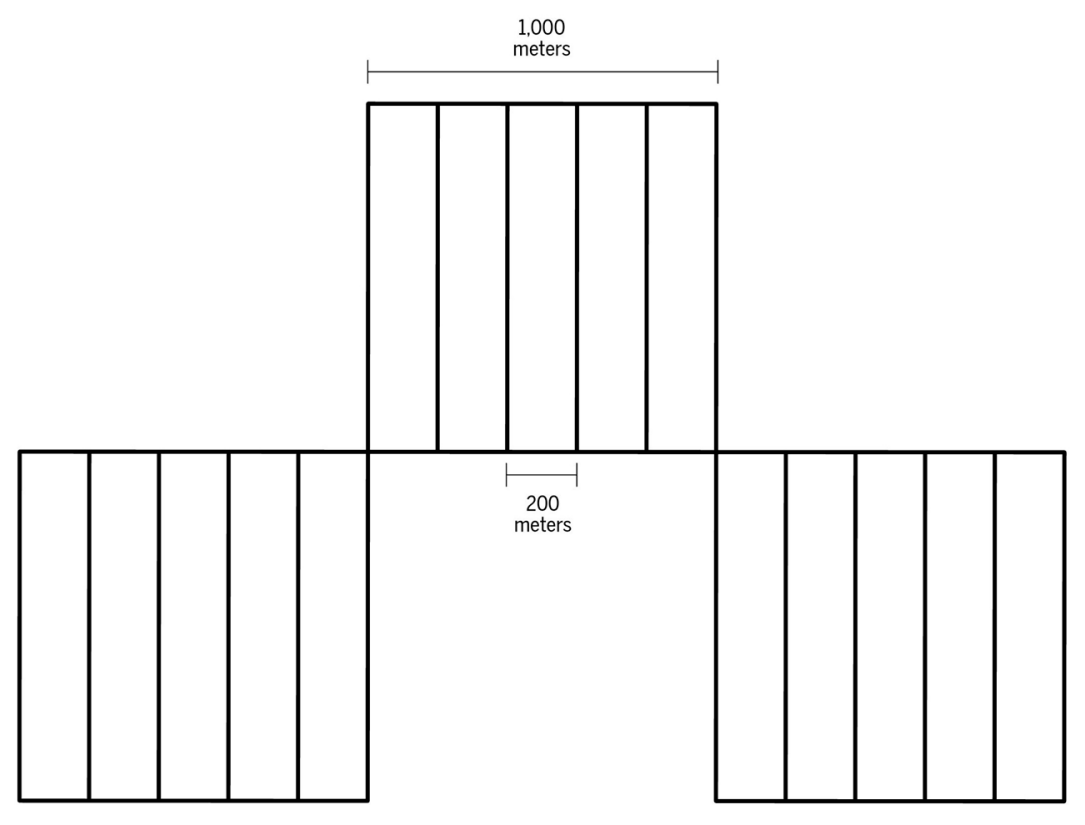

Figure 2. Nest density field plot.

Unburned snag forests were identified using annual records of tree mortality from aerial surveys of the U.S. Forest Service's Forest Health Monitoring Program (www.fs.fed.us/r5/spf/fhp/fhm), and personal knowledge of locations with high recent snag recruitment from natural disturbance processes other than fire (e.g., drought, windthrow). We focused on patches with snag recruitment occurring $<6$ years earlier, and predominantly comprised of areas with $>50 \mathrm{snags} / \mathrm{ha}$. Since such areas are highly patchy on the landscape, we located the 300 ha plots to encompass the greatest proportion of highest recent tree mortality, and with the least amount of post-disturbance logging (all the plots had $<15 \%$ post-disturbance logging).

For burned snag forests, we sampled in 2014 the Wheeler fire of 2007 in the Plumas National Forest (northern Sierra Nevada), and in 2015 the Rim fire of 2013 in the Stanislaus National Forest (central Sierra Nevada). Since fire areas that are $\leq 7$ years post-fire are far less spatially extensive than general forest areas, we systematically arranged the plots with the southwest corner of each 300 ha plot located at the intersection of each increment of $1.25 \mathrm{~min}$ of longitude and latitude. The plots were comprised predominantly of moderate/high-severity fire [25], and plots on which $>15 \%$ of the total area had been post-fire logged were excluded.

Some plots that would otherwise have met the study criteria in one of the three categories were excluded due to their extreme steep slopes and inaccessibility.

From 2014 through to 2016, we surveyed the general forest, unburned snag forest, and burned snag forest plots to find black-backed woodpecker nests. All the surveys were conducted from May 17th through to June 8 th of each year, during the peak of the nesting season, and the surveys occurred only from 6 a.m. to noon each day [2,12]. All the plots were surveyed completely within a single nesting season, and none were surveyed in more than one year.

Within each plot, the surveys followed the methods of Russell et al. (2009) [12] and Dudley and Saab (2003) [26]. In a given plot, surveys were conducted by a three-person team, with each person surveying a different 100-hectare subplot at any given time, then rotating, such that each subplot was surveyed by each of the three team members over a period of several days. Within each square 100 ha subplot, the surveyors searched for black-backed woodpecker nests by meandering within each of five adjacent $200 \times 1000 \mathrm{~m}$ strips. Surveyors stopped every $200 \mathrm{~m}$ of distance within each $1000 \mathrm{~m}$ strip length to conduct a 6-minute broadcast of the recorded black-backed woodpecker calls and drumming [27]. The broadcast was played for $30 \mathrm{~s}$ at a standardized volume, followed by $90 \mathrm{~s}$ of listening, and this was repeated three times during each $6 \mathrm{~min}$ broadcast survey [27]. When any 
black-backed woodpeckers were detected by sight or sound, surveyors tracked them to their nests, provided that the nests were within the plot boundaries, taking the time necessary to do this $[12,26]$. Each surveyor had the plot, subplot, and strip locations within each subplot on GPS units. Under this method, each plot required five to nine days for a three-person team to complete, with an additional 2-3 days for each plot for travel and time to recover from exhaustion and minor injuries.

This method has been found to have a probability of nest detection of $>99 \%$ [12]. The surveyors all received training specific to this study prior to surveys. Based on these methods, we report nest densities (nests $/ \mathrm{km}^{2}$ ) for general forest, unburned snag forest, and burned snag forest. We used a chi-square trend test [28] to determine whether the black-backed woodpecker nest density increased across the three habitat conditions, with the lowest levels in the general forest, intermediate levels in the unburned snag forest, and highest levels in the burned snag forest.

When black-backed woodpecker nests were found within plots, we determined the snag basal area in the nest core by measuring the diameter of all snags over $10 \mathrm{~cm}$ in diameter in 12 0.01-hectare square plots in the four cardinal directions from the nest tree, with four such plots at $15 \mathrm{~m}$ from the nest, four plots at $50 \mathrm{~m}$, and four at $200 \mathrm{~m}$ (Figure 3).

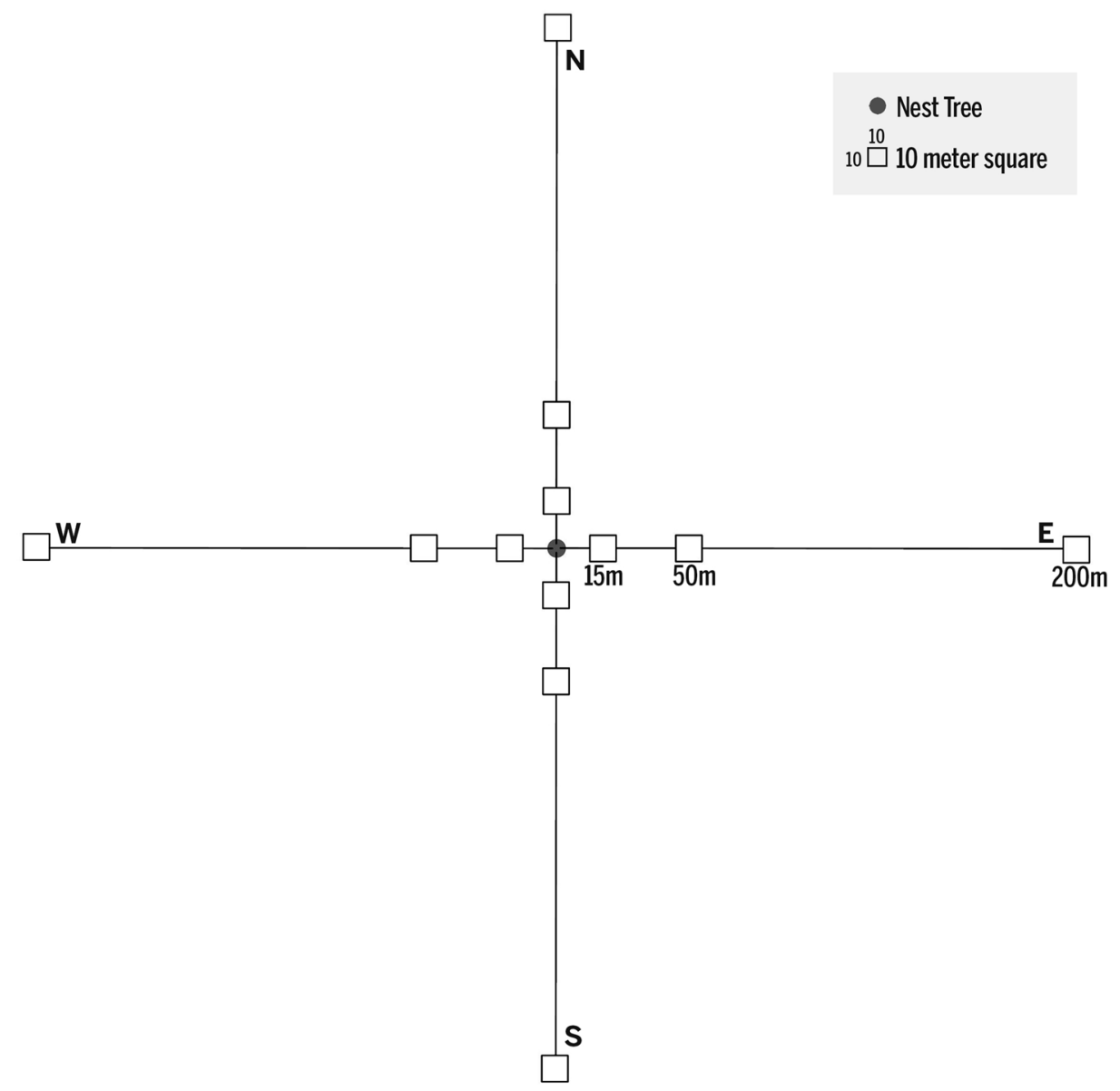

Figure 3. Snag basal area plot arrangement.

\subsection{Landscape Estimation of Suitable Habitat and Population Size}

We determined the snag basal area at the landscape scale using data from the U.S. Forest Service FIA (Forest Inventory and Analysis) fixed plots, for the most recent FIA survey year after our field work was completed, 2017, in all land ownerships combined across the entire Sierra Nevada management region (north of Lake Isabella), within the forest types used by black-backed woodpeckers: mixed-conifer, white fir, red fir, Jeffrey pine, lodgepole pine, subalpine forest types, eastside pine, and eastside mixed-conifer (https://www.fs.usda.gov/detail/r5/landmanagement/gis/ 
?cid=STELPRDB5327836). We used these forest-type data to determine the overall landscape within which black-backed woodpecker nest sites might potentially occur, if suitable habitat was present, and the FIA snag basal area data to determine the proportion of this landscape that contains suitable black-backed woodpecker habitat, based on three different thresholds: (a) one standard deviation below the mean snag basal area from the nest sites in our plots; (b) the conservative "potential" habitat threshold of $>17.4 \mathrm{~m}^{2} /$ ha of snag basal area from Tingley et al. (2014) [2] and Casas et al. (2016) [29]; and (c) the "optimal" habitat threshold of $>25.5 \mathrm{~m}^{2} / \mathrm{ha}$ of snag basal area from Tingley et al. (2014) [2] and Casas et al. (2016) [29]. We derived a range of black-backed woodpecker population estimates in the Sierra Nevada management region by multiplying the area of suitable habitat in each of these three categories by the nest density figures resulting from our field plot surveys.

\section{Results}

\subsection{Field Data}

We surveyed five general forest plots, five unburned snag forest plots, and three burned snag forest plots (Figure 1). We found a total of 0,2 , and 5 active black-backed woodpecker nests in the general forest, unburned snag forest, and burned snag forest plots, respectively. This equates to 0 nests $/ \mathrm{km}^{2}$ in the general forest, 0.13 nests $/ \mathrm{km}^{2}$ in the unburned snag forest, and 0.56 nests $/ \mathrm{km}^{2}$ in the burned snag forest, with an overall density of 0.29 nests $/ \mathrm{km}^{2}(0.0029$ nests/ha) in the two snag forest categories combined. While $0 \%$ of the general forest plots had nests, $20 \%$ of our unburned snag forest plots had nests, and $67 \%$ of our burned snag forest plots had nests. There was a significant trend of increasing nests from general forest to unburned snag forest to burned snag forest $\left(\chi^{2}=4.43, \mathrm{df}=1, p=0.035\right)$.

While it was beyond the scope of our study to comprehensively monitor nest success, our team did observe outcomes for four nests: three burned snag forest nests were successful, fledging one to two young each, and one unburned snag forest nest was unsuccessful.

In the territories within the burned snag forest, the snag basal area within a 200-meter radius around the nest tree had a mean of $35.2 \mathrm{~m}^{2} / \mathrm{ha}$ (in one of the post-fire territories, substantial snag blowdown occurred after the nesting season but before the snag basal area plots were conducted; therefore, we did not conduct snag basal area plots in this territory, since the data would not be representative of the conditions during the nesting season). In the two unburned snag forest territories, the snag basal area was 57.8 and $53.1 \mathrm{~m}^{2} /$ ha, respectively. Overall, the snag basal area in the occupied black-backed woodpecker territories had a mean of $42.0 \mathrm{~m}^{2} /$ ha (S.D. $=17.7 \mathrm{~m}^{2} /$ ha). Therefore, suitable black-backed woodpecker habitat, based on our results and approach, is represented by areas with $>24.3 \mathrm{~m}^{2} / \mathrm{ha}$ (mean minus one standard deviation) of snag basal area.

\subsection{Landscape Estimation of Suitable Habitat and Population Size}

A total area of 3,459,055 ha is comprised of the forest types occupied by black-backed woodpeckers across the Sierra Nevada management region (mixed-conifer, white fir, red fir, Jeffrey pine, lodgepole pine, subalpine forest types, eastside pine, and eastside mixed-conifer), and 195 FIA plots were surveyed in these forest types in this area during 2017. Of the 195 FIA plots, in terms of the snag basal area, 4.6\% met the "optimal" habitat threshold [2,29], 5.1\% met the suitable habitat threshold derived for this study, and $7.7 \%$ met the broader "potential" habitat threshold [2,29], corresponding to suitable habitat areas of $159,117,176,412$, and 266,347 ha, respectively. Using the nest density figure of 0.0029 nests/ha of snag forest habitat from our results, this equates to population estimates of 461 pairs, 512 pairs, and 772 pairs, respectively, for the Sierra Nevada management region. Based on the FIA plots from 2017, the snag basal area in the Sierra Nevada forests is quite low, overall. Of the 195 FIA plots, $56.4 \%$ have a snag basal area of $\leq 3 \mathrm{~m}^{2} / \mathrm{ha}, 15.9 \%$ have a snag basal area of $3.1-6.0 \mathrm{~m}^{2} / \mathrm{ha}$, $11.3 \%$ have $6.1-10.0 \mathrm{~m}^{2} / \mathrm{ha}, 9.7 \%$ have $10.1-20.0 \mathrm{~m}^{2} / \mathrm{ha}$, and only $6.7 \%$ have a snag basal area of $>20 \mathrm{~m}^{2} /$ ha. The forests in our study area are generally lacking old forests. Based on the 195 FIA plots, 
$14.9 \%$ were $\leq 50$ years old, $33.8 \%$ were $51-100$ years old, $25.1 \%$ were $101-150$ years old, $13.3 \%$ were $151-200$ years old, $9.7 \%$ were $201-300$ years old, and $3.2 \%$ were $>300$ years old.

\section{Discussion}

Based on an unprecedented black-backed woodpecker nest density survey effort in terms of spatial scope and intensity in California, we found black-backed woodpeckers nesting only in snag forest habitat, mostly burned, and also in some unburned snag forest. Moreover, we found that the snag forest habitat, with snag basal area densities sufficient to constitute suitable black-backed woodpecker habitat and in the forest types in which black-backed woodpeckers live, is spatially very rare in the forests of the Sierra Nevada, despite recent large fires and snag recruitment from drought and native bark beetles.

In unburned snag forests, our snag basal area results in the two nest areas we found are roughly similar to those of black-backed woodpecker territories in Goggans et al. (1989) [6] in the eastern Oregon Cascades, where $>50 \%$ of the basal area was comprised of snags due to a significant occurrence of snag recruitment from drought and native bark beetles, in forests with an overall basal area of $50-85 \mathrm{~m}^{2} /$ ha. Siegel et al. (2013) [30] reported a mean snag basal area of $43.1 \mathrm{~m}^{2} /$ ha within $50 \mathrm{~m}$ of black-backed woodpecker nests in burned snag forests of the northern Sierra Nevada, similar to our snag basal area results within $200 \mathrm{~m}$ of nest trees in burned snag forests. Tingley et al. (2014) [2] found a mean of $25.5 \mathrm{~m}^{2} /$ ha of snag basal area within home ranges in burned forests. In mostly burned forests in the Black Hills of South Dakota, black-backed woodpeckers selected, for foraging, stands with $30-60 \mathrm{~m}^{2} / \mathrm{ha}$ of basal area, in which $>65 \%$ of the trees were snags [4]. While the methods of these studies are not directly comparable to our methods, there is strong general consistency regarding the importance of snag basal area in the range of $20-30 \mathrm{~m}^{2} /$ ha or higher for successful black-backed woodpecker territories.

Our black-backed woodpecker nest density results are also broadly similar to other research, indicating that few nests went undetected in previous studies, despite the fact that they were not focused on a rigorous and comprehensive assessment of nest density. For example, in Goggans et al. (1989) [6] there was approximately one black-backed woodpecker nest per 400 ha of unburned snag forest habitat. While this density is higher than our results in unburned snag forest (one nest per 750 ha), Goggans et al. (1989) [6] was conducted in one relatively small, discrete study area with extraordinarily high snag basal area levels, as discussed above. Such habitat is extremely rare in the Sierra Nevada within unburned forests in the forest types inhabited by black-backed woodpeckers.

In burned snag forests, we found, on average, one black-backed woodpecker nest per 180 ha, very consistent with the density of one nest per 182 ha reported by Saab et al. (2007) [31] in burned snag forests of the northern Rocky Mountains, and higher than the one nest per 415 ha reported in the Jasper fire in the Black Hills of South Dakota [32]. Consistent with the findings of Tingley et al. (2016) [11], the nest density in our results was much higher in the northern Sierra Nevada than in Sierran forests farther south. In our northern Sierra Nevada burned forest plot, we found one nest per 75 ha, similar to other black-backed woodpecker nest density data in burned forests of the northern Sierra, such as Tarbill et al. (2015) (one nest per 64 ha) [33] and Burnett et al. (2011) (one nest per 78 ha) [34].

Population estimates for black-backed woodpeckers in the Sierra Nevada are lacking in the scientific literature. Nevertheless, given the relatively short time period during which black-backed woodpeckers can use snag forests [3], once natural disturbance processes have created such habitats, and given the small populations estimated by Tingley et al. (2016) [11] in four fire areas in the Sierra Nevada, we believe that our range of estimates is generally consistent with such research. Moreover, our finding that black-backed woodpecker nest densities are considerably higher in burned snag forest than in unburned snag forest is broadly in line with Tingley et al. (2020) [35], who reported that, in the Sierra Nevada, black-backed woodpeckers were nearly 13 times more likely to be detected in fire areas than in unburned forests with many recent "beetle-killed" trees. 
Like many other native birds of the Sierra Nevada that are associated with snag forest habitat, black-backed woodpeckers and their habitat face serious threats from fire suppression and post-fire logging [36], the latter of which heavily and disproportionately targets suitable black-backed woodpecker habitat and occupied nest sites [20]. Commercial "thinning" logging operations, which selectively remove many of the trees in forest stands, are also a threat, since such projects often reduce the overall forest basal area to levels that preclude the potential for sufficient snag densities to comprise suitable black-backed woodpecker habitat, even if high-severity fire later occurs in such areas [37].

Moreover, our findings suggest another substantial threat to black-backed woodpecker populations which warrants attention. Specifically, our data indicate that black-backed woodpeckers depend on exceptionally high levels of snag basal area in both burned and unburned old forests for nesting-a finding that resonates with previous research on this species in unburned forests $[4,6,8,9,16]$. However, large snags, resulting from cycles of drought and native bark beetles, are routinely logged on private forestlands in the Sierra Nevada and in national forests, which comprise most of the forest habitat in this mountain range; the current rangewide forest plan encourages the "salvage" logging of large snags in both burned and unburned forests for the economic interests of the timber industry and the U.S. Forest Service (USFS 2004). The Sierra Nevada forest plan suggests that only 10-15 snags/ha should be retained in any given stand on the national forests of the western Sierra Nevada, and that only 7.5 snags/ha should be retained in forests of the eastern Sierra Nevada [10] (USFS 2004). Based on our data and the previous work of others in unburned forests $[4,6,8,9,16]$, there is no realistic scenario under which such minimal snag retention levels could maintain suitable black-backed woodpecker habitat in unburned forests in terms of the snag basal area/ha.

Significantly, the forest plan specifically targets the densest, oldest forests for logging operations (USFS 2004), which disproportionately impacts a species like the black-backed woodpecker, as it is associated with very high levels of snag basal area that, in unburned forests, are generally found in some dense, old forests $[6,8,9]$. The black-backed woodpecker nests that we found in unburned snag forest were located in old-growth forest stands with a high overall basal area-roughly half of which was comprised of snags. In contrast, all of our general forest plots were dominated by mature and old forest, but did not have the recent substantial pulse of snag recruitment [23] that characterized our unburned snag forest plots. Most mature/old unburned forests of the Sierra Nevada have low levels of snags due to "salvage" logging, while the landscape is interspersed with patches of forest with much higher snag levels, following severe drought [23]. The overall deficit of snags in this landscape, and the ongoing forest management policies oriented toward preventing increased snag densities, pose a significant threat to black-backed woodpecker populations. Though unburned snag forest habitat may not provide optimal prey resources or camouflage from avian predators for black-backed woodpeckers, compared to burned snag forests [7], the unburned snag forests play an important role in sustaining black-backed woodpecker populations [7,9].

In light of our findings, and given the ongoing threats to black-backed woodpeckers and their habitat from fire suppression, the logging of both burned and unburned forests, and the lack of any current meaningful protections for suitable habitat or active nest locations, increased protections for this species are warranted, including Species of Conservation Concern designation through the U.S. Forest Service [20] and listing under the Endangered Species Act.

Author Contributions: Both authors contributed substantially to the design and field work for this study, and the writing of the manuscript. T.Y.C. contributed relatively more to the field work, and C.T.H. contributed relatively more to the design and manuscript writing. All authors have read and agree to the published version of the manuscript.

Funding: This research was funded by Environment Now foundation (grants \#2014, 2015, 2016, and 2017).

Acknowledgments: Special thanks are due to the several wildlife biologists who helped us conduct the black-backed woodpecker nest density surveys for this project, including Maya Khosla, Christy Sherr, Craig Swolgaard, Kevin Kilpatrick, Matt York, Kim Glinka, Christine Heckler, and Robert Thompson. We also thank Gretchen Padgett-Flohr for assistance, and GreenInfo Network for the GIS analysis and production of the study area map and FIA data sorting, along with the Environment Now foundation for providing funding to 
carry out this study. Finally, we thank the reviewers, whose thoughtful comments and suggestions improved this manuscript.

Conflicts of Interest: The authors declare no conflict of interest.

\section{References}

1. Hanson, C.T.; North, M.P. Postfire woodpecker foraging in salvage-logged and unlogged forests of the Sierra Nevada. Condor 2008, 110, 777-782. [CrossRef]

2. Tingley, M.W.; Wilkerson, R.L.; Bond, M.L.; Howell, C.A.; Siegel, R.B. Variation in home-range size of Black-backed woodpeckers. Condor 2014, 116, 325-340. [CrossRef]

3. Saracco, J.F.; Siegel, R.B.; Wilkerson, R.L. Occupancy modeling of Black-backed Woodpeckers on burned Sierra Nevada forests. Ecosphere 2011, 2, 31. [CrossRef]

4. Rota, C.T.; Rumble, M.A.; Millspaugh, J.J.; Lehman, C.P.; Kesler, D.C. Space-use and habitat associations of Black-backed Woodpeckers (Picoides arcticus) occupying recently disturbed forests in the Black Hills, South Dakota. For. Ecol. Manag. 2014, 313, 161-168. [CrossRef]

5. Fogg, A.M.; Roberts, L.J.; Burnett, R.D. Occurrence patterns of black-backed woodpeckers in green forest of the Sierra Nevada Mountains, California, USA. Avian Conserv. Ecol. 2014, 9, 3. [CrossRef]

6. Goggans, R.; Dixon, R.D.; Seminara, L.C. Habitat Use by Three-Toed and Black-Backed Woodpeckers, Deschutes National Forest, Oregon; Oregon Department of Fish and Wildlife Nongame Program: Bend, OR, USA, 1989.

7. Rota, C.T.; Millspaugh, J.J.; Rumble, M.A.; Lehman, C.P.; Kesler, D.C. The role of wildfire, prescribed fire, and mountain pine beetle infestations on the population dynamics of Black-backed Woodpeckers in the Black Hills, South Dakota. PLoS ONE 2014, 9, e94700. [CrossRef]

8. Tremblay, J.A.; Ibarzabal, J.; Dussault, C.; Savard, J.-P.L. Habitat requirements of breeding black-backed woodpeckers in unburned boreal forest. Avian Conserv. Ecol. 2009, 4, 2. [CrossRef]

9. Tremblay, J.A.; Savard, J.-P.L.; Ibarzabal, J. Structural retention requirements for a key ecosystem engineer in conifer-dominated stands of a boreal managed landscape in eastern Canada. For. Ecol. Manag. 2015, 357, 220-227. [CrossRef]

10. USFS. Sierra Nevada Forest Plan Amendment, Final Environmental Impact Statement and Record of Decision; U.S. Forest Service, Pacific Southwest Region: Vallejo, CA, USA, 2004.

11. Tingley, M.W.; Wilkerson, R.L.; Howell, C.A.; Siegel, R.B. An integrated occupancy and space-use model to predict abundance of imperfectly detected, territorial vertebrates. Methods Ecol. Evol. 2016, 7, 508-517. [CrossRef]

12. Russell, R.E.; Saab, V.A.; Rotella, J.J.; Dudley, J.G. Detection probabilities of woodpecker nests in mixed conifer forests in Oregon. Wilson J. Ornithol. 2009, 121, 82-88. [CrossRef]

13. Baker, W.L. Historical forest structure and fire in Sierran mixed-conifer forests reconstructed from General Land Office survey data. Ecosphere 2014, 5, 79. [CrossRef]

14. DellaSala, D.A.; Hanson, C.T. (Eds.) The Ecological Importance of Mixed-Severity Fires: Nature's Phoenix; Elsevier Inc.: Waltham, MA, USA, 2015.

15. Hanson, C.T. Post-Fire Management of Snag Forest Habitat in the Sierra Nevada. Ph.D. Thesis, University of California at Davis, Davis, CA, USA, 2007.

16. Tremblay, J.A.; Ibarzabal, J.; Savard, J.-P.L. Contribution of unburned boreal forests to the population of black-backed woodpecker in eastern Canada. Écoscience 2015, 22, 145-155. [CrossRef]

17. Tremblay, J.A.; Dixon, R.D.; Saab, V.A.; Pyle, P.; Patten, M.A. Black-backed Woodpecker (Picoides arcticus), version 1.0. In Birds of the World; Rodewald, P.G., Ed.; Cornell Lab of Ornithology: Ithaca, NY, USA, 2020.

18. Mallek, C.; Safford, H.; Viers, J.; Miller, J. Modern departures in fire severity and area vary by forest type, Sierra Nevada and southern Cascades, USA. Ecosphere 2013, 4, 153. [CrossRef]

19. Doerr, S.H.; Santín, C. Global trends in wildfire and its impacts: Perceptions versus realities in a changing world. Philos. Trans. R. Soc. B 2016, 371, 20150345. [CrossRef] [PubMed]

20. DellaSala, D.A.; Hutto, R.L.; Hanson, C.T.; Bond, M.L.; Ingalsbee, T.; Odion, D.; Baker, W.L. Accomodating mixed-severity fire to restore and maintain ecosystem integrity with a focus on the Sierra Nevada of California, USA. Fire Ecol. 2017, 13, 148-171. [CrossRef]

21. White, A.M.; Tarbill, G.L.; Wilkerson, B.; Siegel, R. Few detections of Black-backed Woodpeckers (Picoides arcticus) in extreme wildfires in the Sierra Nevada. Avian Conserv. Ecol. 2019, 14, 17. [CrossRef] 
22. DellaSala, D.A.; Hanson, C.T. Are wildland fires increasing large patches of complex early seral forest habitat? Diversity 2019, 11, 157. [CrossRef]

23. Byer, S.; Jin, Y. Detecting drought-induced tree mortality in Sierra Nevada forests with time series of satellite data. Remote Sens. 2017, 9, 929. [CrossRef]

24. Restaino, C.; Young, D.; Estes, B.; Gross, S.; Wuenschel, A.; Meyer, M.; Safford, H. Forest structure and climate mediate drought-induced tree mortality in forests of the Sierra Nevada, USA. Ecol. Appl. 2019, 29 , e01902. [CrossRef]

25. Miller, J.D.; Thode, A.E. Quantifying burn severity in a heterogeneous landscape with a relative version of the delta Normalized Burn Ratio (dNBR). Remote Sens. Environ. 2007, 109, 66-80. [CrossRef]

26. Dudley, J.G.; Saab, V.A. A Field Protocol to Monitor Cavity-Nesting Birds. USDA, Forest Service, Research Paper RMRS-RP-44; Rocky Mountain Research Station: Fort Collins, CO, USA, 2003.

27. Siegel, R.B.; Tingley, M.W.; Wilkerson, R.L. Black-Backed Woodpecker MIS Surveys on Sierra Nevada National Forests: 2011 Annual Report. A Report in Fulfillment of U.S. Forest Service Agreement No. 08-CS-11052005-201, Modification \#4; U.S. Forest Service Pacific Southwest Region: Vallejo, CA, USA, 2012.

28. Zar, J.H. Biostatistical Analysis, 5th ed.; Prentice Hall, Inc.: Upper Saddle River, NJ, USA, 2010.

29. Casas, A.; García, M.; Siegel, R.B.; Koltunov, A.; Ramírez, C.; Ustin, S. Burned forest characterization at single-tree level with airborne laser scanning for assessing wildlife habitat. Remote Sens. Environ. 2016, 175, 231-241. [CrossRef]

30. Siegel, R.B.; Tingley, M.W.; Wilkerson, R.L.; Bond, M.L.; Howell, C.A. Assessing Home Range Size and Habitat Needs of Black-Backed Woodpeckers in California: Report for the 2011 and 2012 Field Seasons; Institute for Bird Populations: Point Reyes Station, CA, USA, 2013.

31. Saab, V.A.; Russell, R.E.; Dudley, J.G. Nest densities of cavity-nesting birds in relation to postfire salvage logging and time since wildfire. Condor 2007, 109, 97-108. [CrossRef]

32. Vierling, K.T.; Lentile, L.B.; Nielsen-Pincus, N. Preburn characteristics and woodpecker use of burned coniferous forests. J. Wildl. Manag. 2008, 72, 422-427. [CrossRef]

33. Tarbill, G.L.; Manley, P.N.; White, A.M. Drill, baby, drill: The influence of woodpeckers on post-fire vertebrate communities through cavity excavation. J. Zool. 2015, 296, 95-103. [CrossRef]

34. Burnett, R.D.; Taillie, P.; Seavy, N. Plumas Lassen Study 2010 Annual Report; U.S. Forest Service, Pacific Southwest Region: Vallejo, CA, USA, 2011.

35. Tingley, M.W.; Stillman, A.N.; Wilkerson, R.L.; Sawyer, S.C.; Siegel, R.B. Black-backed woodpecker occupancy in burned and beetle-killed forests: Disturbance agent matters. For. Ecol. Manag. 2020, 455, 117694. [CrossRef]

36. Hanson, C.T. Conservation concerns for Sierra Nevada birds associated with high-severity fire. West. Birds 2014, 45, 204-212.

37. Hutto, R.L. The ecological importance of severe wildfires: Some like it hot. Ecol. Appl. 2008, 18, 1827-1834. [CrossRef]

(C) 2020 by the authors. Licensee MDPI, Basel, Switzerland. This article is an open access article distributed under the terms and conditions of the Creative Commons Attribution (CC BY) license (http://creativecommons.org/licenses/by/4.0/). 